\title{
Neutrophil Integrins and Matrix Ligands and NET Release
}

\author{
Xian M. O'Brien ${ }^{1,2}$ and Jonathan S. Reichner ${ }^{1,2 *}$ \\ ${ }^{1}$ Division of Surgical Research, Department of Surgery, Rhode Island Hospital, Providence, RI, USA, ${ }^{2}$ Warren Alpert Medical \\ School, Brown University, Providence, RI, USA
}

Neutrophils are motile and responsive to tissue injury and infection. As neutrophils emigrate from the bloodstream and migrate toward a site of affliction, they encounter the tissue extracellular matrix (ECM) and thereby engage integrins. Our laboratory studies the neutrophilic response to the fungal pathogen Candida albicans either in the filamentous state of the microbe or to the purified pathogen-associated molecular pattern, $\beta$-glucan. We have gained an appreciation for the role of integrins in regulating the neutrophil anti-Candida response and how the presence or absence of ECM can drive experimental outcome. The $\beta 2$ integrin CR3 (complement receptor 3; $\alpha \mathrm{M} \beta 2$; Mac-1; CD11b/CD18) plays an important role in fungal recognition by its ability to bind $\beta$-glucan at a unique lectin-like domain. The presence of ECM differentially regulates essential

OPEN ACCESS

Edited by:

Mariana Julieta Kaplan,

National Institute of Arthritis and Musculoskeletal and Skin Diseases,

USA

Reviewed by: lan Dransfield,

University of Edinburgh, UK Yan-Qing Ma,

Blood Center of Wisconsin, USA

${ }^{*}$ Correspondence: Jonathan S. Reichner reichner@brown.edu

Specialty section:

This article was submitted to

Molecular Innate Immunity, a section of the journal Frontiers in Immunology

Received: 29 July 2016 Accepted: 02 September 2016 Published: 19 September 2016

Citation:

O'Brien XM and Reichner JS (2016) Neutrophil Integrins and Matrix Ligands and NET Release. Front. Immunol. 7:363. doi: 10.3389/fimmu.2016.00363 neutrophil anti-fungal functions, including chemotaxis, respiratory burst, homotypic aggregation, and the release of neutrophil extracellular traps (NETs). We have shown that NET release to $C$. albicans hyphae or immobilized $\beta$-glucan occurs rapidly and without the requirement for respiratory burst on ECM. This is in contrast to the more frequently reported mechanisms of NETosis to other pathogens without the context of ECM, which occur after a prolonged lag period and require respiratory burst. As expected for an ECM-dependent phenotype, NETosis and other neutrophil functions are dependent on specific integrins. The focus of this review is the role of ECM ligation by neutrophil integrins as it pertains to host defense functions with an emphasis on lessons we have learned studying the anti-Candida response of human neutrophils.

Keywords: NETs, extracellular matrix, neutrophils, integrins, Candida

\section{PREVALENCE AND RISK FACTORS FOR CANDIDIASIS}

Candida albicans exists as normal flora of the skin and GI tract but can become a serious and lifethreatening infection. Candidiasis can present either locally as mucocutaneous infection or as the more severe invasive form of the disease. Predisposing factors lending to loss of host control of the colonized organism are likely to be a combination of host as well as microbial factors (1). Invasive candidiasis continues to be a significant medical problem and Candida ranks as the fourth leading pathogen in causing nosocomial infection with mortality up to $40 \%$ in spite of available anti-fungal

Abbreviations: CARD9, caspase recruitment domain-containing protein 9; CR3, complement receptor 3; ECM, extracellular matrix; LAD, leukocyte adhesion deficiency; NETs, neutrophil extracellular traps; PAD4, peptidyl arginine deiminase type IV; PAMP, pathogen-associated molecular pattern; PRR, pattern recognition receptor; ROS, reactive oxygen species. 
therapy (2). Infection can take place in any bodily organ and systemic infection can involve coincident infection of multiple organs, as well as the blood.

Clinical risk factors for acquisition of Candida infection include neutropenia or a neutrophil defect whether heritable or epigenetic, systemic antibiotic usage, central venous catheter, mucosal damage, and prolonged stay in the ICU even in the presence of surfeit neutrophils $(3,4)$. Candida infection is remarkably high in non-trauma emergency surgical patients with a prolonged ICU stay, reaching a rate of 21.7/100 discharges, higher than other established high-risk populations $(5,6)$.

\section{FUNGAL RECOGNITION}

Candida albicans is a polymorphic fungal pathogen that can grow as yeast, pseudohyphae, and true hyphae and the ability to switch between phenotypic states is an essential virulence factor complicating immune detection (7-9). Neutrophils respond to infectious fungi in a variety of ways, including phagocytosis, production of reactive oxygen species (ROS), degranulation, recruitment of other leukocytes, and the more recently recognized release of neutrophil extracellular traps (NETs). In its budding yeast form, C. albicans is small enough for neutrophils to phagocytose. This response involves uptake of microbes into the phagosome, where fusion of cytotoxic granules and oxidative products facilitate microbial killing (10). The invasive filamentous forms of C. albicans are too large to be engulfed, necessitating other cellular strategies for anti-fungal response and clearance (11-16). The recently described process of NETosis, where NETs consisting primarily of DNA studded with histones and components of cytotoxic granules are extruded into the extracellular space, accomplishes the dual functions of both immobilizing and killing harmful microbes where phagocytosis is not feasible (17).

Innate immune cells recognize $C$. albicans by binding to molecules present in the fungal cell wall. $\beta$-glucans are a class of long-chain polymers of glucose in $\beta-(1,3)(1,6)$-linkages that are conserved in microbial structures but not found in mammalian cells and, thus, are considered a pathogen-associated molecular pattern (PAMP) $(11,18,19)$. Pattern recognition receptors (PRRs) on cells of the innate immune system discern PAMPs as being non-self and initiate antimicrobial host defense mechanisms through activation of intracellular signaling pathways. With regard to recognition of $\beta$-glucan, two receptors have received the most attention; the integrin CR3 and the C-type lectin Dectin-1 that may exert non-overlapping roles in clinical and experimental host defense. To parse the relative roles of these receptors, one must take into account the species of the host and immune cell type being studied as the anti-fungal role of these receptors can differ between monocyte/macrophages and neutrophils. Differences may also lie in the specific immune function being assayed and the morphological form of the Candida.

Dectin-1 plays a key role in C. albicans control in mice such that mice defective in Dectin-1 are susceptible to fungal infections while CR3 knockout mice are more resistant to challenge with disseminated C. albicans, suggesting that CR3 has a nonprotective, or suppressive effect on murine host defense (20). In humans, Dectin-1 has been shown to be important in control of mucocutaneous but not systemic infection $(21,22)$. This was supported by a study of a family with a mutation of caspase recruitment domain-containing protein 9 (CARD9), a signaling molecule downstream of Dectin-1 (23). In this family, the CARD9 defect presented as a predisposition to mucocutaneous candidiasis similar to the absence of Dectin-1, mediated by a cytokine production defect of monocytes and macrophages (21, 23). Neutrophils from leukocyte adhesion deficiency (LAD) type 1 patients that are devoid of CD11b/CD18 but which express Dectin-1 failed to internalize Saccharomyces cerevisiae or unopsonized zymosan demonstrating the primacy of CR3 in phagocytosis of unicellular yeast and $\beta$-glucan-containing particles (24). In short, phagocytosis of unopsonized yeast or $\beta$-glucan-containing particles is primarily mediated by CR3 in human phagocytes and by Dectin-1 in murine cells (25). It is not clear why the genetic absence of CR3 has such different implications for anti-fungal immunity in mice and humans. This is often correlated with the notion that CR3 ligation by $\beta$-glucan particles fails to induce respiratory burst thereby limiting this host defense mechanism (26). However, we and others have shown that human neutrophils induce a CR3-dependent respiratory burst to fungal hyphae or immobilized purified $\beta$-glucan as a model of the response to nonphagocytosable filaments $(11,12,15)$. Given the multifaceted role of CR3 in immune response to a pathogen, it is difficult to ascribe a mechanism to the increased resistance in CR3 knockout mice.

With regard to recognition of non-phagocytosable fungal hyphae, our laboratory showed that antibody blockade of either fungal cell wall $\beta$-glucan or neutrophil CR3 was sufficient to obviate the respiratory burst of human neutrophils; antibody blockage of Dectin-1 had no effect $(11,13)$. In addition to the host defense mechanisms affected by CR3 and Dectin-1 individually, there is solid evidence for a crosstalk pathway connecting these PRRs. Li et al. showed a mechanism dependent on the RhoGTPase exchange factor, Vav, through which binding of $\beta$-glucan to Dectin-1 resulted in CR3 activation in both murine and human cells (27). This highlights the potential complexity of working toward a more complete understanding of the differential nature of immune recognition of $C$. albicans hyphae and yeast forms. A significant step forward in this regard is found in a report by Lowman et al. (22) in which a novel cyclical, or "closed chain" structure of $\beta$-glucan was found in $C$. albicans hyphae but not in yeast. These authors purified $\beta$-glucan from $C$. albicans yeast and hyphae into water-insoluble microparticulate form and showed that the $\beta$-glucan extracted from hyphae, but not yeast, produced a potent IL-1 response by human monocytes and macrophages, which was Dectin-1-dependent. Whether monocyte Dectin-1 can recognize cyclical hyphal $\beta$-glucan within the cell wall of the organism remains to be seen. Findings to date suggest that Dectin-1 recognition of Candida hyphae is limited to bud scars where $\beta$-glucan is particularly exposed, it does not appear to recognize $\beta$-glucan along hyphal filaments (28). Whether neutrophils exhibit differential responsiveness to these $\beta$-glucan isoforms has not yet been determined. Therefore, the differential responsiveness of innate immune cells to the yeast and hyphal forms of C. albicans may well be due to variance in the structure of the prominent fungal PAMP $\beta$-glucan. Work from our laboratory and others show that CR3 is most likely the prominent immune 
receptor on human neutrophils and is able to detect $\beta$-glucan within fungal filaments $(11,13,15,29)$. As CR3 serves as both a PRR and an extracellular matrix (ECM)-binding integrin, it plays a critical role in integrating tissue environment and microbial recognition, driving neutrophil anti-fungal immunity.

\section{ROLE OF INTEGRINS IN ANTI-FUNGAL IMMUNITY}

All cell-cell and cell-ECM adhesive events occur extracellularly but are translated into cellular responses by communication across the plasma membrane through the action of integrins (30). Integrins are essential for proper regulation of a number of fundamental physiological processes, including tissue morphogenesis, inflammation, immune responsiveness, wound healing, and regulation of cell growth and differentiation. All cells express a contingent of integrins and respond to integrin activation by cytoskeletal-dependent processes, such as shape change, adhesion, spreading, migration, and/or phagocytosis (31). Among 24 $\alpha \beta$ heterodimers that have been reported in vertebrates, the $\beta 2$ family $(\alpha \mathrm{L} \beta 2, \alpha \mathrm{M} \beta 2, \alpha \mathrm{X} \beta 2$, and $\alpha \mathrm{D} \beta 2)$ are specifically expressed on leukocytes (31). Leukocyte $\beta 2$ integrins regulate many aspects of immune or inflammatory responses because, unlike cells that reside within solid tissues, circulating leukocytes by necessity relocate during the course of immune reactions. In so doing, they dynamically adhere and de-adhere to cells of the vasculature, to other immune cells, and to components of the ECM, in order to ultimately contact the foreign body or pathogen at the site of infection or injury. Evidence for the physiological significance of leukocyte integrins is highlighted by the recurrent, lifethreatening infectious episodes observed in LAD patients that are genetically deficient for expression of $\beta 2$ integrins (32). In stark contrast to impaired host defense found in the absence of $\beta 2$ integrins, sustained and improper activation of these integrins contributes to the pathogenesis of autoimmune diseases, chronic inflammatory disorders, and ischemic stroke (33).

Complement receptor 3 (CR3; $\alpha \mathrm{M} \beta 2$; CD11b/CD18; Mac-1) is a member of the $\beta 2$ integrin family, yet it functions like no other integrin and, in some ways, like no other receptor yet described in nature. In general, receptors can be defined as having a canonical ligand that binds with characteristic affinity to a single binding site which, in turn, leads to a characteristic intracellular response. In stark contrast, CR3 has two spatially distinct binding sites, the so-called I-domain and the lectin-like domain, that bind completely different ligands and results in differing cellular responses. The I-domain itself is a highly promiscuous binding site with over 30 structurally unrelated ligands shown to be capable of binding at that domain alone, including $\mathrm{iC} 3 \mathrm{~b}$, fibrinogen, ICAM-1, fibronectin, heparan sulfate, and factor X $(34,35)$. I-domain ligands are both host- and microbial-derived such that a multitude of immune effector functions executed by inflammatory neutrophils are entirely mediated, or regulated, by CR3. As with other integrins, ligand binding is regulated by the structural state of activation such that when in a bent conformation the integrin is in a low-affinity state that is modulated upon activating signals that can originate internally (inside-out) or externally (outside-in). In either case, the receptor assumes an upright conformation consistent with high-affinity ligand binding that can be further regulated by receptor clustering resulting in avidity modulation (36). The lectin-like domain is spatially distinct from the I-domain, and is noted for its ability to bind the glucose polymer $\beta$-glucan $(11,18,37-39)$. Ligation of purified fungal $\beta$-glucan to CR3 is sufficient to induce a signaling response (39). The ability of CR3 to mediate neutrophil recognition of fungi and initiate signaling identifies it as the only integrin that also serves as a PRR.

A novel aspect of CR3 bioactivity is that the manner in which it is ligated at its two binding domains has a profound effect on cellular responsiveness. This concept was first posited where Vetvicka et al. reported that murine and human natural killer cells could acquire cytotoxic capability for resistant tumor cells if targets were opsonized with iC3b, a well-described CR3 I-domain ligand, and effector cells were exposed to $\beta$-glucan, but not by either ligand alone (40-42). This increased cytotoxic activity could be inhibited with CR3-specific antibodies. Administration of $\beta$-glucan enhanced the activity of complement-fixing, anti-tumor antibodies in vivo, causing tumor regression and increased survival as compared to mice receiving either antibody or $\beta$-glucan alone (43-45). Surprisingly, this adjuvant activity of $\beta$-glucan in reducing tumor burden was shown to be mediated by neutrophils and did not occur in mice lacking either CR3 or complement or in mice depleted of neutrophils.

\section{ROLE OF EXTRACELLULAR MATRIX IN ANTI-FUNGAL IMMUNITY}

In a seminal paper by Carl Nathan in 1989, the respiratory burst of human neutrophils to soluble proinflammatory mediators was shown to be adhesion dependent and require attachment to either ECM components or human umbilical vein endothelial cells $(46,47)$. This adhesion dependence of neutrophil effector function provided an early the basis for suggesting the coordination of integrin and non-integrin stimuli to drive host defense in tissues. As CR3 mediates cellular interactions with ECM, and since all neutrophilic responses to tissue infections necessitate ECM contact, we focused our attention on investigating the role of CR3 as a fungal PRR via the lectin-like domain in the presence of fibronectin, a ubiquitous ECM molecule and I-domain ligand. We showed that the effect of CR3 on the anti-fungal response of human neutrophils to Candida is not a straightforward consequence of receptor ligation, but is directed by how it is ligated $(11-13,39,48-52)$. We have found that upon dual ligation of CR3 by fibronectin and $\beta$-glucan, neutrophils demonstrated enhanced chemotaxis, swarming and aggregation, NETosis, and an actively suppressed respiratory burst (Figure 1). Antibodyblocking studies were used to show coincident ligation of CR3 at both the I-domain with the ECM component fibronectin and the lectin-like domain control neutrophil effector functions differently than ligation of either site alone (11-13, 39, 49-52). These studies additionally identified a CR3-mediated regulation of $\beta 1$ integrins, driving a shift in fibronectin binding from $\alpha 5 \beta 1$ to $\alpha 3 \beta 1$ $(12,50,52)$. 

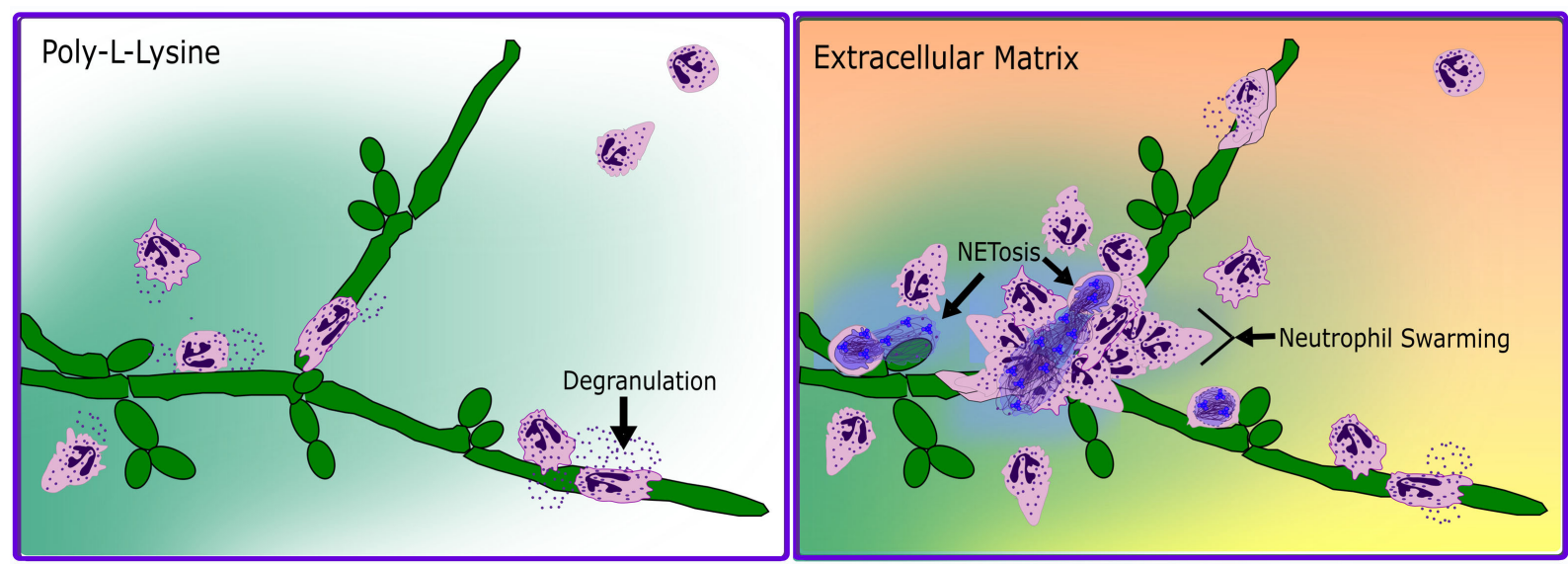

FIGURE 1 | Schematized neutrophil response to $\boldsymbol{C}$. albicans hyphae in the absence and presence of extracellular matrix. In the absence of ECM (poly-L-lysine, left panel), neutrophils respond to hyphae by chemotaxis, by degranulation and respiratory burst, and by wrapping around fungal filaments in a form of frustrated phagocytosis. In the presence of ECM (Extracellular Matrix, right panel), neutrophils chemotaxis to fungal filaments is faster and more directed, with degranulation and respiratory burst being actively suppressed until the multifocal contact of frustrated phagocytosis. Additionally, in a subset of cells contacting the fungal hyphae, a rapid, respiratory burst independent NETotic response is induced and followed by neutrophil swarming.

In order to be virulent, $C$. albicans must be capable of transitioning between yeast and hyphal forms (53). The yeast form is readily cleared by neutrophil phagocytosis, the mechanisms of which have been studied extensively. Less work has focused on the neutrophilic response to this filamentous form of the microbe. As Candida destruction necessitates a full-blown response to both forms of the organism, work in our lab has focused on this gap in our understanding of anti-fungal host defense. We found that $C$. albicans hyphae growing in the kidney of an infected rat induced massive clustering of inflammatory neutrophils that entirely surrounded the hyphae (11). This clustering of human neutrophils could be replicated in vitro with C. albicans hyphae plated on fibronectin but not on hyphae plated in the absence of fibronectin (13). Pretreating hyphae with an anti- $\beta$-glucan antibody prevented clustering of neutrophils suggesting that the $\beta$-glucan component of the fungal cell wall is important for neutrophil responsiveness (13). Immobilization of purified $\beta$-glucan in the presence of fibronectin was a biomimic for Candida hyphae within tissue ECM suggesting that fungal $\beta$-glucan is necessary and sufficient for homotypic aggregation (13). Furthermore, this swarming and aggregation took place rapidly, being evident in less than $30 \mathrm{~min}$ in vitro (13).

\section{ADDING NETosis TO THE REPERTOIRE OF NEUTROPHIL-MEDIATED IMMUNITY}

NETosis was initially described as a pathway of chromatin decondensation and release with requisite NADPH oxidase, elastase, and myeloperoxidase activity in response to activating stimuli (54-56). The initial reports showed relatively slow kinetics, occurring hours following exposure to stimuli, including bacteria, fungi, or PMA $(14,17,54,55,57,58)$, though evidence suggests that no de novo gene synthesis is required (59). As additional investigators explored conditions necessary and sufficient to
NET release within their experimental systems, some variance in the original paradigm emerged. The "classical" pathway involves entry of the neutrophil into a cell death program that requires ROS and manifests in plasma membrane disruption and NET release $1-4 \mathrm{~h}$ after stimulation. This pathway utilized peptidyl arginine deiminase type IV (PAD4) for histone citrullination that leads to chromatin decondensation due to neutralization of histone electrostatic charge normally imparted by arginine but lost upon conversion to citrulline (60). Elastase and myeloperoxidase serve to digest nuclear histones after translocation such that absence of these enzymes impairs NET release (61). A more recently identified early/rapid, or "vital," NET release was identified that can result in extrusion in minutes, independently of ROS and without compromising cell viability, in response to Staphylococcus aureus, C. albicans, and Leishmania promastigotes $(13,62,63)$. The "classical" and "vital" NETosis pathways need not be mutually exclusive, as the context of NETotic stimuli presentation, such as timing, viability, size, or morphotype, can drive differential response patterns and kinetics $(13,14,54,57$, 62-64). ECM ligands in the context of tissue infection can also drive differential neutrophil responses.

\section{ROLE OF INTEGRINS AND EXTRACELLULAR MATRIX IN THE REGULATION OF NETosis}

Our laboratory has demonstrated an integrin-dependent ECM response that both actively suppresses the respiratory burst to Candida hyphae, or immobilized fungal $\beta$-glucan, while driving a robust, rapid NETotic response $(12,13)$. Additionally, work with neonatal neutrophils show that this NETotic anti-fungal pathway is active even though neonatal neutrophils have been shown to be deficient in NETotic responses to other initiating agents, 
underscoring the importance of stimuli context in evaluating effector function $(65,66)$.

In addition to our work, evidence to date describes the role of $\beta 2$ integrins in NET release as it occurs along liver sinusoids or vascular endothelium. Platelet-neutrophil interactions have been shown to occur under conditions of severe sepsis (67) or endotoxemia in which activation of platelet TLR4 promotes platelet binding to neutrophils with ensuing NET release (68). Two recent studies differ with regard to which $\beta 2$ integrin mediates platelet-neutrophil binding. McDonald et al. (69) show a role for LFA1, although the ligand on the platelet remains to be defined. Rossaint et al. (70) showed that incubation of stimulated platelets with neutrophils ex vivo induced NETosis that could be blocked with anti-CR3 antibodies but not with antibodies against LFA1. Mohanty et al. (71) recently identified that neutrophils form NETs from saliva exposure in a $\beta 2$ integrin-independent fashion, as LAD1 patients form NETs to saliva and PMA but not to unopsonized $S$. aureus.

Complement receptor-3 has been shown to regulate apoptosis of neutrophils such that the genetic absence of CR3 delayed the onset of apoptosis of neutrophils after thioglycollate injection (72). Given that CR3 determines a NETotic pathway for Candida, it is of interest to consider whether or not NETotic and apoptotic pathways have common points of regulation. Evidence to date suggests that NETosis and apoptosis both require calcium for initiation but then show divergence in the sense that PAD4 activation does not depend on downstream components of the apoptotic pathway, such as activated caspase, and apoptosis does not depend on PAD4 (73). Indeed, histone citrullination in neutrophils is induced by inflammatory stimuli and not by treatments that induce apoptosis (73). Moreover, treatment of neutrophil-differentiated HL60 cells with calcium ionophore showed that histone citrullination preceded PARP cleavage, such that the decision-making events may be temporal.

The occupancy of one integrin by ligand has been shown to be capable of suppressing the function of other integrins in a phenomenon referred to as trans-dominant inhibition, or integrin crosstalk. For example, activating antibodies specific for the $\alpha v \beta 3$ integrin suppress $\alpha 5 \beta 1$-dependent phagocytosis and ligation of $\alpha 4 \beta 1$ inhibits $\alpha 5 \beta 1$-dependent expression of metalloproteinases $(74,75)$. Ligation of $\alpha \operatorname{IIb} \beta 3$ induces trans-dominant suppression

\section{REFERENCES}

1. Johnson A. The biology of mating in Candida albicans. Nat Rev Microbiol (2003) 1:106-16. doi:10.1038/nrmicro752

2. Kullberg BJ, Arendrup MC. Invasive candidiasis. N Engl J Med (2015) 373:1445-56. doi:10.1056/NEJMra1315399

3. Spellberg BJ, Filler SG, Edwards JE. Current treatment strategies for disseminated candidiasis. Clin Infect Dis (2006) 42:244-51. doi:10.1086/499057

4. Wang X, van de Veerdonk FL, Netea MG. Basic genetics and immunology of candida infections. Infect Dis Clin North Am (2016) 30:85-102. doi:10.1016/ j.idc. 2015.10 .010

5. Vincent JL, Anaissie E, Bruining H, Demajo W, el-Ebiary M, Haber J, et al. Epidemiology, diagnosis and treatment of systemic candida infection in surgical patients under intensive care. Intensive Care Med (1998) 24:206-16. doi:10.1007/s001340050552

6. Kourkoumpetis T, Manolakaki D, Velmahos G, Chang Y, Alam HB, De Moya MM, et al. Candida infection and colonization among non-trauma of target integrins $\alpha 5 \beta 1$ and $\alpha 2 \beta 1$ (76). Additionally, antibody activation of $\beta 1$ integrins was shown to increase CR3 adhesion to fibronectin (77) and outside-in activation of $\beta 2$ integrins via crosslinking was demonstrated to upregulate the expression of $\beta 1$ integrins (78). These studies suggest that certain integrinspecific ligands provoke integrin crosstalk that could result in alterations in cell migration and invasion. With regard to the anti-Candida response of human neutrophils, we discovered a temporal, interregulatory relationship between the $\beta 2$ integrin CR 3 and regulation of $\beta 1$ family members and this modulates the response to $\beta$-glucan or $C$. albicans hyphae in the context of ECM $(12,13,49-52)$. The extent to which integrin crosstalk operates as a regulatory pathway for other innate immune functions is not well understood.

\section{NEUTROPHILS, INTEGRINS, EXTRACELLULAR MATRIX, NETosis, AND BEYOND}

The host response of neutrophils to C. albicans-infected tissues necessitates ECM contact. Our work and others have clearly demonstrated a regulatory role of ECM in determining neutrophil function, including NETosis. The focus of this review, the role of ECM ligation by neutrophil integrins as it pertains to both host defense functions and the kinetics of these functions, has implications that reach far beyond the anti-fungal response. The totality of ECM involvement in neutrophil host defense in tissues makes accounting for both its presence and the role of integrin engagement an important and under-examined mechanistic aspect of inflammation.

\section{AUTHOR CONTRIBUTIONS}

$\mathrm{XO}$ and JR conceived, designed, and wrote the manuscript.

\section{FUNDING}

This work was supported by the NIH grant GM066194 and HL125265 (JR). Work was also supported by funds from the Department of Surgery, Rhode Island Hospital.

emergency surgery patients. Virulence (2010) 1:359-66. doi:10.4161/viru.1. 5.12795

7. Lo H-J, Köhler JR, DiDomenico B, Loebenberg D, Cacciapuoti A, Fink GR. Nonfilamentous C. albicans mutants are avirulent. Cell (1997) 90:939-49. doi:10.1016/S0092-8674(00)80358-X

8. Berman J, Sudbery PE. Candida albicans: a molecular revolution built on lessons from budding yeast. Nat Rev Genet (2002) 3:918-30. doi:10.1038/ nrg948

9. Gow NAR, van de Veerdonk FL, Brown AJP, Netea MG. Candida albicans morphogenesis and host defence: discriminating invasion from colonization. Nat Rev Microbiol (2011) 10:112. doi:10.1038/nrmicro2711

10. Winterbourn CC, Kettle AJ. Redox reactions and microbial killing in the neutrophil phagosome. Antioxid Redox Signal (2013) 18:642-60. doi:10.1089/ ars.2012.4827

11. Lavigne LM, Albina JE, Reichner JS. Beta-glucan is a fungal determinant for adhesion-dependent human neutrophil functions. JImmunol (2006) 177:8667-75. doi:10.4049/jimmunol.177.12.8667 
12. Lavigne LM, O’Brien XM, Kim M, Janowski JW, Albina JE, Reichner JS. Integrin engagement mediates the human polymorphonuclear leukocyte response to a fungal pathogen-associated molecular pattern. J Immunol (2007) 178:7276-82. doi:10.4049/jimmunol.178.11.7276

13. Byrd AS, O’Brien XM, Johnson CM, Lavigne LM, Reichner JS. An extracellular matrix-based mechanism of rapid neutrophil extracellular trap formation in response to Candida albicans. J Immunol (2013) 190:4136-48. doi:10.4049/ jimmunol.1202671

14. Branzk N, Lubojemska A, Hardison SE, Wang Q, Gutierrez MG, Brown GD, et al. Neutrophils sense microbe size and selectively release neutrophil extracellular traps in response to large pathogens. Nat Immunol (2014) 15:1017-25. doi:10.1038/ni.2987

15. Leal SM, Vareechon C, Cowden S, Cobb BA, Latgé J-P, Momany M, et al. Fungal antioxidant pathways promote survival against neutrophils during infection. J Clin Invest (2012) 122:2482-98. doi:10.1172/JCI63239

16. Wozniok I, Hornbach A, Schmitt C, Frosch M, Einsele H, Hube B, et al. Induction of ERK-kinase signalling triggers morphotype-specific killing of Candida albicans filaments by human neutrophils. Cell Microbiol (2008) 10:807-20. doi:10.1111/j.1462-5822.2007.01086.x

17. Urban CF, Reichard U, Brinkmann V, Zychlinsky A. Neutrophil extracellular traps capture and kill Candida albicans yeast and hyphal forms. Cell Microbiol (2006) 8:668-76. doi:10.1111/j.1462-5822.2005.00659.x

18. Xia Y, Vetvicka V, Yan J, Hanikýrová M, Mayadas T, Ross GD. The beta-glucan-binding lectin site of mouse CR3 (CD11b/CD18) and its function in generating a primed state of the receptor that mediates cytotoxic activation in response to iC3b-opsonized target cells. J Immunol (1999) 162:2281-90.

19. Phaff H. Cell wall of yeasts. Annu Rev Microbiol (1963) 17:15-30. doi:10.1146/ annurev.mi.17.100163.000311

20. Romani L, Montagnoli C, Bozza S, Perruccio K, Spreca A, Allavena P, et al. The exploitation of distinct recognition receptors in dendritic cells determines the full range of host immune relationships with Candida albicans. Int Immunol (2004) 16:149-61. doi:10.1093/intimm/dxh012

21. Ferwerda B, Ferwerda G, Plantinga TS, Willment JA, van Spriel AB, Venselaar $\mathrm{H}$, et al. Human dectin-1 deficiency and mucocutaneous fungal infections. N Engl J Med (2009) 361:1760-7. doi:10.1056/NEJMoa0901053

22. Lowman DW, Greene RR, Bearden DW, Kruppa MD, Pottier M, Monteiro MA, et al. Novel structural features in Candida albicans hyphal glucan provide a basis for differential innate immune recognition of hyphae versus yeast. J Biol Chem (2014) 289:3432-43. doi:10.1074/jbc.M113.529131

23. Glocker E-O, Hennigs A, Nabavi M, Schäffer AA, Woellner C, Salzer U, et al. A homozygous CARD9 mutation in a family with susceptibility to fungal infections. N Engl J Med (2009) 361:1727-35. doi:10.1056/NEJMoa0810719

24. van Bruggen R, Drewniak A, Jansen M, van Houdt M, Roos D, Chapel H, et al. Complement receptor 3, not Dectin-1, is the major receptor on human neutrophils for beta-glucan-bearing particles. Mol Immunol (2009) 47:575-81. doi:10.1016/j.molimm.2009.09.018

25. Brown GD. Dectin-1: a signalling non-TLR pattern-recognition receptor. Nat Rev Immunol (2006) 6:33-43. doi:10.1038/nri1745

26. Wright SD, Silverstein SC. Receptors for C3b and C3bi promote phagocytosis but not the release of toxic oxygen from human phagocytes. J Exp Med (1983) 158:2016-23. doi:10.1084/jem.158.6.2016

27. Li X, Utomo A, Cullere X, Choi MM, Milner DA, Venkatesh D, et al. The $\beta$-glucan receptor dectin-1 activates the integrin Mac-1 in neutrophils via Vav protein signaling to promote Candida albicans clearance. Cell Host Microbe (2011) 10:603-15. doi:10.1016/j.chom.2011.10.009

28. Gantner BN, Simmons RM, Underhill DM. Dectin-1 mediates macrophage recognition of Candida albicans yeast but not filaments. EMBO J (2005) 24:1277-86. doi:10.1038/sj.emboj.7600594

29. Forsyth CB, Mathews HL. Lymphocyte adhesion to Candida albicans. Infect Immun (2002) 70:517-27. doi:10.1128/IAI.70.2.517-527.2002

30. Hynes RO. Integrins: bidirectional, allosteric signaling machines. Cell (2002) 110:673-87. doi:10.1016/S0092-8674(02)00971-6

31. Hynes RO. Integrins: versatility, modulation, and signaling in cell adhesion. Cell (1992) 69:11-25. doi:10.1016/0092-8674(92)90115-S

32. Bauer TR, Hickstein DD. Gene therapy for leukocyte adhesion deficiency. Curr Opin Mol Ther (2000) 2:383-8.

33. Yung RL, Ray D, Mo RR, Chen JT. Cell integrin overexpression as a model of murine autoimmunity. Biol Proced Online (2003) 5:211-21. doi:10.1251/ bpo64
34. Yakubenko VP, Lishko VK, Lam SC-T, Ugarova TP. A molecular basis for integrin alphaMbeta 2 ligand binding promiscuity. JBiol Chem (2002) 277:48635-42. doi:10.1074/jbc.M208877200

35. Diamond MS, Garcia-Aguilar J, Bickford JK, Corbi AL, Springer TA. The I domain is a major recognition site on the leukocyte integrin Mac-1 (CD11b/ CD18) for four distinct adhesion ligands. J Cell Biol (1993) 120:1031-43. doi:10.1083/jcb.120.4.1031

36. Kim M, Carman CV, Yang W, Salas A, Springer TA. The primacy of affinity over clustering in regulation of adhesiveness of the integrin alphaL, beta2. J Cell Biol (2004) 167:1241. doi:10.1083/jcb.200404160

37. Xia Y, Ross GD. Generation of recombinant fragments of CD11b expressing the functional beta-glucan-binding lectin site of CR3 (CD11b/CD18). J Immunol (1999) 162:7285-93.

38. Ross GD. Regulation of the adhesion versus cytotoxic functions of the Mac-1/CR3/alphaMbeta2-integrin glycoprotein. Crit Rev Immunol (2000) 20:197-222. doi:10.1615/CritRevImmunol.v20.i3.20

39. O’Brien XM, Heflin KE, Lavigne LM, Yu K, Kim M, Salomon AR, et al. Lectin site ligation of CR3 induces conformational changes and signaling. J Biol Chem (2012) 287:3337-48. doi:10.1074/jbc.M111.298307

40. Vetvicka V, Thornton BP, Ross GD. Soluble beta-glucan polysaccharide binding to the lectin site of neutrophil or natural killer cell complement receptor type 3 (CD11b/CD18) generates a primed state of the receptor capable of mediating cytotoxicity of iC3b-opsonized target cells. J Clin Invest (1996) 98:50-61. doi:10.1172/JCI118777

41. Větvicka V, Hanikýrová M, Větvicková J, Ross GD. Regulation of CR3 (CD11b/CD18)-dependent natural killer (NK) cell cytotoxicity by tumour target cell MHC class I molecules. Clin Exp Immunol (1999) 115:229-35. doi:10.1046/j.1365-2249.1999.00800.x

42. Vetvicka V, Thornton BP, Wieman TJ, Ross GD. Targeting of natural killer cells to mammary carcinoma via naturally occurring tumor cell-bound $\mathrm{iC} 3 \mathrm{~b}$ and beta-glucan-primed CR3 (CD11b/CD18). J Immunol (1997) 159:599-605.

43. Hong F, Hansen RD, Yan J, Allendorf DJ, Baran JT, Ostroff GR, et al. Beta-glucan functions as an adjuvant for monoclonal antibody immunotherapy by recruiting tumoricidal granulocytes as killer cells. Cancer Res (2003) 63:9023-31.

44. Hong F, Yan J, Baran JT, Allendorf DJ, Hansen RD, Ostroff GR, et al. Mechanism by which orally administered beta-1,3-glucans enhance the tumoricidal activity of antitumor monoclonal antibodies in murine tumor models. J Immunol (2004) 173:797-806. doi:10.4049/jimmunol.173.2.797

45. Li B, Allendorf DJ, Hansen R, Marroquin J, Ding C, Cramer DE, et al. Yeast beta-glucan amplifies phagocyte killing of iC3b-opsonized tumor cells via complement receptor 3-Syk-phosphatidylinositol 3-kinase pathway. J Immunol (2006) 177:1661-9. doi:10.4049/jimmunol.177.3.1661

46. Nathan C, Srimal S, Farber C, Sanchez E, Kabbash L, Asch A, et al. Cytokineinduced respiratory burst of human neutrophils: dependence on extracellular matrix proteins and CD11/CD18 integrins. J Cell Biol (1989) 109:1341-9. doi:10.1083/jcb.109.3.1341

47. Nathan CF. Neutrophil activation on biological surfaces. Massive secretion of hydrogen peroxide in response to products of macrophages and lymphocytes. J Clin Invest (1987) 80:1550-60. doi:10.1172/JCI113241

48. Fox ED, Heffernan DS, Cioffi WG, Reichner JS. Neutrophils from critically ill septic patients mediate profound loss of endothelial barrier integrity. Crit Care (2013) 17:R226. doi:10.1186/cc13049

49. Harler MB, Reichner J. Increased neutrophil motility by beta-glucan in the absence of chemoattractant. Shock (2001) 16:419-24. doi:10.1097/00024382200116060-00003

50. Harler MB, Wakshull E, Filardo EJ, Albina JE, Reichner JS. Promotion of neutrophil chemotaxis through differential regulation of beta 1 and beta 2 integrins. J Immunol (1999) 162:6792-9.

51. Tsikitis VL, Albina JE, Reichner JS. Beta-glucan affects leukocyte navigation in a complex chemotactic gradient. Surgery (2004) 136:384-9. doi:10.1016/ j.surg.2004.05.014

52. Tsikitis V, Morin NA, Harrington EO, Ablina JE, Reichner JS. The lectin-like domain of complement receptor 3 protects endothelial barrier function from activated neutrophils. J Immunol (2004) 173:1284-91. doi:10.4049/ jimmunol.173.2.1284

53. Whiteway M, Oberholzer U. Candida morphogenesis and host-pathogen interactions. Curr Opin Microbiol (2004) 7:350-7. doi:10.1016/j.mib.2004 06.005 
54. Brinkmann V, Reichard U, Goosmann C, Fauler B, Uhlemann Y, Weiss DS, et al. Neutrophil extracellular traps kill bacteria. Science (2004) 303:1532-5. doi:10.1126/science.1092385

55. Fuchs TA, Abed U, Goosmann C, Hurwitz R, Schulze I, Wahn V, et al. Novel cell death program leads to neutrophil extracellular traps. J Cell Biol (2007) 176:231-41. doi:10.1083/jcb.200606027

56. Steinberg BE, Grinstein S. Unconventional roles of the NADPH oxidase: signaling, ion homeostasis, and cell death. Sci STKE (2007) 2007:e11. doi:10.1126/stke.3792007pe11

57. Urban CF, Ermert D, Schmid M, Abu-Abed U, Goosmann C, Nacken W, et al. Neutrophil extracellular traps contain calprotectin, a cytosolic protein complex involved in host defense against Candida albicans. PLoS Pathog (2009) 5:e1000639. doi:10.1371/journal.ppat.1000639

58. Bruns S, Kniemeyer O, Hasenberg M, Aimanianda V, Nietzsche S, Thywissen A, et al. Production of extracellular traps against Aspergillus fumigatus in vitro and in infected lung tissue is dependent on invading neutrophils and influenced by hydrophobin RodA. PLoS Pathog (2010) 6:e1000873. doi:10.1371/ journal.ppat.1000873

59. Sollberger G, Amulic B, Zychlinsky A, Amulic B, Cazalet C, Hayes GL, et al. Neutrophil extracellular trap formation is independent of de novo gene expression. PLoS One (2016) 11:e0157454. doi:10.1371/journal.pone.0157454

60. Wang Y, Li M, Stadler S, Correll S, Li P, Wang D, et al. Histone hypercitrullination mediates chromatin decondensation and neutrophil extracellular trap formation. J Cell Biol (2009) 184:205-13. doi:10.1083/jcb.200806072

61. Papayannopoulos V, Metzler KD, Hakkim A, Zychlinsky A. Neutrophil elastase and myeloperoxidase regulate the formation of neutrophil extracellular traps. J Cell Biol (2010) 191:677-91. doi:10.1083/jcb.201006052

62. Pilsczek FH, Salina D, Poon KKH, Fahey C, Yipp BG, Sibley CD, et al. A novel mechanism of rapid nuclear neutrophil extracellular trap formation in response to Staphylococcus aureus. JImmunol (2010) 185:7413-25. doi:10.4049/jimmunol.1000675

63. Rochael NC, Guimarães-Costa AB, Nascimento MTC, DeSouza-Vieira TS, Oliveira MP, Garcia e Souza LF, et al. Classical ROS-dependent and early/ rapid ROS-independent release of neutrophil extracellular traps triggered by Leishmania parasites. Sci Rep (2015) 5:18302. doi:10.1038/srep18302

64. Kenno S, Perito S, Mosci P, Vecchiarelli A, Monari C. Autophagy and reactive oxygen species are involved in neutrophil extracellular traps release induced by C. albicans Morphotypes. Front Microbiol (2016) 7:879. doi:10.3389/ fmicb.2016.00879

65. Byrd AS, O’Brien XM, Laforce-Nesbitt SS, Parisi VE, Hirakawa MP, Bliss JM, et al. NETosis in neonates: evidence of a reactive oxygen species-independent pathway in response to fungal challenge. J Infect Dis (2016) 213:634-9. doi:10.1093/infdis/jiv435

66. Yost CC, Cody MJ, Harris ES, Thornton NL, McInturff AM, Martinez ML, et al. Impaired neutrophil extracellular trap (NET) formation: a novel innate immune deficiency of human neonates. Blood (2009) 113:6419-27. doi:10.1182/blood-2008-07-171629

67. Clark SR, Ma AC, Tavener SA, McDonald B, Goodarzi Z, Kelly MM, et al. Platelet TLR4 activates neutrophil extracellular traps to ensnare bacteria in septic blood. Nat Med (2007) 13:463-9. doi:10.1038/nm1565
68. Caudrillier A, Kessenbrock K, Gilliss BM, Nguyen JX, Marques MB, Monestier M, et al. Platelets induce neutrophil extracellular traps in transfusion-related acute lung injury. J Clin Invest (2012) 122:2661-71. doi:10.1172/ JCI61303

69. McDonald B, Urrutia R, Yipp BG, Jenne CN, Kubes P. Intravascular neutrophil extracellular traps capture bacteria from the bloodstream during sepsis. Cell Host Microbe (2012) 12:324-33. doi:10.1016/j.chom.2012.06.011

70. Rossaint J, Herter JM, Van Aken H, Napirei M, Döring Y, Weber C, et al. Synchronized integrin engagement and chemokine activation is crucial in neutrophil extracellular trap-mediated sterile inflammation. Blood (2014) 123:2573-84. doi:10.1182/blood-2013-07-516484

71. Mohanty T, Sjögren J, Kahn F, Abu-Humaidan AHA, Fisker N, Assing K, et al. A novel mechanism for NETosis provides antimicrobial defense at the oral mucosa. Blood (2015) 126:2128-37. doi:10.1182/blood-2015-04-641142

72. Coxon A, Rieu P, Barkalow FJ, Askari S, Sharpe AH, von Andrian UH, et al. A novel role for the beta 2 integrin CD11b/CD18 in neutrophil apoptosis: a homeostatic mechanism in inflammation. Immunity (1996) 5:653-66. doi:10.1016/S1074-7613(00)80278-2

73. Neeli I, Khan SN, Radic M. Histone deimination as a response to inflammatory stimuli in neutrophils. J Immunol (2008) 180:1895-902. doi:10.4049/ jimmunol.180.3.1895

74. Huhtala P, Humphries MJ, McCarthy JB, Tremble PM, Werb Z, Damsky CH. Cooperative signaling by alpha 5 beta 1 and alpha 4 beta 1 integrins regulates metalloproteinase gene expression in fibroblasts adhering to fibronectin. J Cell Biol (1995) 129:867-79. doi:10.1083/jcb.129.3.867

75. Blystone SD, Graham IL, Lindberg FP, Brown EJ. Integrin alpha v beta 3 differentially regulates adhesive and phagocytic functions of the fibronectin receptor alpha 5 beta 1. J Cell Biol (1994) 127:1129-37. doi:10.1083/jcb. 127.4.1129

76. Díaz-González F, Forsyth J, Steiner B, Ginsberg MH. Trans-dominant inhibition of integrin function. Mol Biol Cell (1996) 7:1939-51. doi:10.1091/ mbc.7.12.1939

77. van den Berg JM, Mul FP, Schippers E, Weening JJ, Roos D, Kuijpers TW. Beta1 integrin activation on human neutrophils promotes beta2 integrin-mediated adhesion to fibronectin. Eur J Immunol (2001) 31:276-84. doi:10.1002/1521-4141(200101)31:1<276:AID-IMMU276>3.0.CO;2-D

78. Werr J, Eriksson EE, Hedqvist P, Lindbom L. Engagement of beta2 integrins induces surface expression of betal integrin receptors in human neutrophils. J Leukoc Biol (2000) 68:553-60.

Conflict of Interest Statement: The authors declare that the research was conducted in the absence of any commercial or financial relationships that could be construed as a potential conflict of interest.

Copyright (c) 2016 O'Brien and Reichner. This is an open-access article distributed under the terms of the Creative Commons Attribution License (CC BY). The use, distribution or reproduction in other forums is permitted, provided the original author(s) or licensor are credited and that the original publication in this journal is cited, in accordance with accepted academic practice. No use, distribution or reproduction is permitted which does not comply with these terms. 